Proc. Estonian Acad. Sci. Biol. Ecol., 2004, 53, 2, 75-87

\title{
Variability of genitalia and pheromone communication channels of Archips podana (Scopoli) (Lepidoptera: Tortricidae)
}

\author{
Ilme Liblikas ${ }^{\mathrm{a}, \mathrm{b}}$, Enno Mõttus ${ }^{\mathrm{a} *}$, Zoya V. Nikolaeva ${ }^{\mathrm{c}}$, Ann Ojarand ${ }^{\mathrm{a}}$, \\ Anna-Karin Borg-Karlson ${ }^{\mathrm{b}}$, Elena I. Ovsyannikova ${ }^{\mathrm{d}}$, Igor Ya. Grichanov ${ }^{\mathrm{d}}$, \\ Tamara V. Ivanova ${ }^{\mathrm{d}}$, and Viktor A. Yemelyanov ${ }^{\mathrm{c}}$ \\ a Estonian Agricultural University, Laboratory of Ecochemistry, Veski 13, 51005 Tartu, Estonia; \\ ilmel@kth.se,annoja@eau.ee \\ b Group of Ecological Chemistry, Chemistry Department, Royal Institute of Technology, Stockholm, \\ SE-10044, Sweden; akbk@kth.se \\ c Agricultural Academy, Matrosova 1, Velikie Luki, Pskovskaya oblast, Russia; madizos@mart.ru, \\ madizos@mart.ru \\ d All-Russian Institute of Plant Protection, VIZR, Sh. Podbelskogo, 3, St.-Petersburg-Pushkin, \\ 196608, Russia; ovsyan@peterlink.ru,grichanov@mail.ru
}

Received 9 January 2004, in revised form 25 February 2004

\begin{abstract}
The large fruit-tree tortrix Archips podana (Scopoli) is a widely distributed species in the whole of Europe. The species is variable in male genitalia. According to the different number and position of apical (A) and lateral (L) spikes on the aedeagus, A, L, 2L, AL, A2L, and 0 (without spike) phenotypes were discriminated. To determine the variability of pheromone communication of A. podana, field trap tests were conducted in different habitats and geographical regions in Estonia (Uhti and Otepää), northwestern Russia (Velikie Luki, Pskov Region), and the North Caucasus (Krasnodar Territory). The optimum content of Z-11-tetradecenyl acetate in pheromone blend, calculated using the Gaussian curve, was on average $61.3 \pm 1.3 \%$. This is practically identical to the ratio of $60: 40$ in the mixture of (Z)- and (E)-11-tetradecen-1-yl acetates identified by Persoons et al. (1994, J. Insect Physiol., 20, 1181-1188). Experiments demonstrated that the optimal pheromone composition was the same in Krasnodar, where the L phenotype dominates, and in Velikie Luki and Estonia, where A phenotype males dominate. A deviation of attractive blend from optimum ratio causes a comparable decrease in trap catches for males of different aedeagus forms. The Caucasian subspecies with a lateral spike (male phenotype L), A. podana meridiana Kozl. et Esart., is placed in synonymy to nominotypical species in this paper. Calculation of pheromone communication parameters - channel width and optimal ratio - is an effective tool for ecochemical research and dispenser modelling.
\end{abstract}

Key words: normal distribution, pheromone communication channel, Archips podana, Tortricidae, phenotypes, population variability, (E)-11-tetradecenyl acetate, (Z)-11-tetradecenyl acetate.

\footnotetext{
*Corresponding author, emottus@eau.ee
} 


\section{INTRODUCTION}

The large fruit-tree tortrix (the omnivorous leafroller, apple surface eating tortricid) Archips podana (Scopoli) is a widely distributed species inhabiting the whole of Europe (Kuznetsov, 1978). Data from Asia Minor need confirmation (Razowski, 1977), whereas records from Siberia and the Far East belong to another species of the genus (Razowski, 1981; Kuznetsov, 1994). Polyphagous A. podana feeds on up to 28 plant species. The most preferable are Betula spp., Fraxinus excelsior, and Ribes spp. Fruit trees such as Prunus, Malus, and Cerasus are moderately inhabited (Litvinova, 1974). In regions with two generations of A. podana it is considered to be an important pest (Persoons et al., 1974), while in regions of one generation its damages are sporadic.

The species is highly variable in fore and hind wing coloration and venation in imagoes (Galetenko, 1964; Razowski, 1977). Ivanova was probably the first to show geographical variability for A. podana male genitalia (Ivanova \& Mõttus, 1986a, 1986b), although Galetenko (1964) had earlier argued that the aedeagus of A. podana (from the Crimean population, Ukraine) had no apical spike (phenotype 0), contrary to many European authors who sketched the aedeagus with an apical spike (phenotype A) (Hannemann, 1963; Kuznetsov, 1978; Razowski, 1981).

Different authors have indicated from 2 to 6 phenotypes of the species (Ivanova \& Mõttus, 1986a; Kozlov \& Motorkin, 1987, 1988; Safonkin, 1987a, 1987b), depending on the number and position of apical (A) and lateral (L) spikes on the aedeagus (A, L, 2L, AL, A2L, 0 as main phenotypes). The combinations may be much more numerous than listed above (Kozlov \& Motorkin, 1987). The presence of lateral and the missing of apical spikes is determined by dominant alleles of at least two nonlinked genes (Kozlov, 1989). Certainly, the number of spikes on the aedeagus has no taxonomic value, as it varies greatly (from 0 to 3 apical and from 0 to 7 lateral ones) in every geographical area and in brooding of one female (Kozlov, 1989; Kozlov \& Motorkin, 1990). Brun et al. (1991) described a population of $A$. podana with a lateral spike as the Corsican variety.

The female sex pheromone of A. podana was identified as 60:40 mixture of (E)- and (Z)-11-tetradecen-1-yl acetates (E11-14:Ac and Z11-14:Ac, respectively) on the basis of chromatography of pheromone gland extracts (Persoons et al., 1974). On the basis of field screening the optimum ratio was estimated at $1: 1$. Numerous subsequent field screening experiments of the described attractant gave discordant results. In The Netherlands and England (Persoons et al., 1974), near Paris (Frérot et al., 1979), and in the Krasnodar Territory (Ivanova \& Mõttus, 1986b), the most attractive was the blend of 1:1 (Z/E). In Belarus (Bykhovets et al., 1986), Central Russia (Ryabchinskaya et al., 1986), and Carpathians region (Safonkin, 1989), the blend of 6:4 (Z/E) was the most attractive. On the basis of published data Ivanova \& Mõttus (1986a) hypothesized differences in the pheromone communication of different phenotypes of $A$. podana. Later Kozlov et al. (1991) found that for the Voronezh population (prevailingly A phenotype) the 
mixture of 50:50 of Z11-14:Ac and E11-14:Ac was significantly more attractive than the 60:40 mixture; the latter was described as the best for the Lagodekhi (Georgia) population (L phenotype). This and some more differences were the basis for determining the Caucasian subspecies of A. podana (males phenotype L) as A. podana meridiana Kozl. et Esart. (Kozlov \& Esartia, 1991).

The population's polymorphism and its relation to chemical communication of A. podana have been intensively discussed in Russian literature (Safonkin, 1987a, 1987b, 1988, 2000; Safonkin \& Buleza, 1988; Kozlov \& Motorkin, 1988, 1990; Kozlov, 1989, 1990, 1991; Kozlov \& Kravchuk, 1991; Mõttus \& Ivanova, 1991). Some dissimilarity in ethology and the EAG response of phenotypes AL and A, as well as different sensitivity of phenotype groups $\mathrm{A}+\mathrm{AL}$ and $\mathrm{L}+0$ have been found (Kozlov \& Motorkin, 1990). Kozlov \& Motorkin (1990) mapped the phenotype ratio for different regions revealed by means of pheromone trapping (attractant with $\mathrm{Z} / \mathrm{E}$ ratio of $33: 66$ was used). Type L strongly dominates (more than $85 \%$ ) in the Caucasus and the adjacent steppe zone, including Slavyansk-na-Kubani and Krasnodar. Consequently the Corsican variety described by Brun et al. (1991) belongs to the phenotype L, widespread in the Caucasus area. Azov and Volgograd have a large fraction of phenotypes $\mathrm{L}$ and $\mathrm{AL}$ and could be considered a transitional area of the domination of phenotype A. The Carpathians males of A. podana have approximately the same phenotype ratio as the rest of central Europe (more than 50\% of phenotype A). Safonkin (1987a, 1987b, 1988, 1990) proposed some correlation with habitat (host plants), but data from Kozlov (1989) did not confirm it.

In case the phenotypes are signs of population varieties, some differences in pheromone communication may be expected. In this paper we report our results on comparison of pheromone communication channels of A. podana in several regions of Russia and in Estonia.

\section{MATERIALS AND METHODS}

\section{Traps and field tests}

Field trap tests were conducted in different habitats and geographical regions in Estonia (Uhti and Otepää), northwestern Russia (environs of Velikie Luki, Pskov Region), and the North Caucasus (environs of Krasnodar) using similar methodology. Traps were hung at least $20 \mathrm{~m}$ apart at a height of $1.5-2.0 \mathrm{~m}$ and were inspected every 5 to 10 days. In Russia cardboard or plastic deltatraps Atrakon ${ }^{\circledR}$ A with a sticky base area of $225 \mathrm{~cm}^{2}$, produced by AS Tartu-Flora, Tartu, Estonia, were used. The entomological glue Pestifix ${ }^{\circledR}$ (Tartu-Flora) was used in the traps. All the experiments in Russia were carried out in five replicates. In Estonia tests were conducted in ten (forest at Otepää) or five replicates.

In trees traps were hung at a height of 1.5-1.8 m. Between the trees with traps at least two trees were left without traps. 


\section{Chemicals}

Compounds used in Feroflor dispensers were assayed by gas chromatography on Carbowax $20 \mathrm{M}$ capillary columns, $30 \mathrm{~m}$, i.d. $0.25 \mathrm{~mm}$. Z11-14:Ac used in Feroflor type dispensers contained about $0.8 \%$ of Z-11-tetradecenol (Z11-14:OH), and E11-14:Ac had about 0.4\% of the corresponding alcohol (E11-14:OH). The accuracy of the ratio of the components and doses in the dispensers were checked using gas chromatography and was found as $\pm 1 \%$. E11-14:Ac used in Miniket dispensers did not contain a detectable amount of E11-14:OH. The content of $\mathrm{Z} 11-14: \mathrm{OH}$ was $0.1 \%$ in Z11-14:Ac.

\section{Dispensers}

Feroflor type dispensers were used in experiments before 1999 (Mõttus \& Ivanova, 1991). In 2000 and later Miniket type dispensers were used. Miniket dispensers were loaded with $1 \mathrm{mg}$ of a mixture of Z11-14:Ac and E11-14:Ac with a content of $20,40,50,60,70$, or $80 \%$ of $\mathrm{Z}$ isomer. Feroflor dispensers were loaded with blends having different ratios of the isomers. The half-life of tetradecenyl acetate isomers exceeds 4 months. The evaporation rate of the mixture from the dispensers in field did not exceed $70 \mathrm{ng} / \mathrm{h}$. The volatility of $\mathrm{Z}$ and $\mathrm{E}$ isomers of 11-tetradecenyl acetate from the dispensers was considered equal (Mõttus et al., 2001).

\section{Calculation of the optimum ratio of a pheromone blend}

The concept of communication channel width was introduced by Howse et al. (1998). Here we use the calculated optimum ratio of isomers as one of the quantitative characteristics of pheromone communication channels. Having trap catch data for dispensers with a different content of one component $(x)$ we used the Gaussian curve

$$
f(x)=\frac{A}{\sigma \sqrt{2 \pi}} \exp \left(-\frac{(x-\mu)^{2}}{2 \sigma^{2}}\right)+y_{0},
$$

where $\mu$ is the location of the maximum and $\sigma$ is a parameter describing the width of the curve, to calculate the optimal content of one compound, $x_{\max }$, in two-component attractant blend. For our purpose, Eq. (1) may be written as

$$
y=\frac{A}{w_{\mathrm{c}} \sqrt{\frac{\pi}{2}}} \exp \left(-\frac{\left(x_{\max }-x\right)^{2}}{w_{\mathrm{c}}{ }^{2}}\right)+y_{0},
$$

where $w_{\mathrm{c}}$ is the width of the pheromone communication channel (approximately equal to two standard deviations) and $x_{\max }$ is used instead of the maximum location $\mu$. 
The width of the pheromone communication channel $w_{\mathrm{c}}$ characterizes the influence of component ratio on trap catches. As seen from Eq. (2), if the content of a substance is equal to $x_{\max } \pm 0.5 w_{\mathrm{c}}$, the trap catch equals $y=e^{-0.5}=0.61$ or $61 \%$ of the maximum trap catch. In case the change of the component ratio in effluvia equals $x_{\max } \pm 0.4 \sigma$, the mean trap catches are $10 \%$ lower than $y_{\max }$. Obviously, $w_{\mathrm{c}}$ may be used as a measure of the pheromone communication channel width (Mõttus et al., 2001).

\section{Statistical analysis and calculations}

Trap catch data for the tested blends were subjected to ANOVA and, following a significant $F$ value, differences between treatments were determined (Sokal \& Rohlf, 1986). To calculate the optimal content of the attractive blend the built-in Gauss normal distribution function of the "Origin" program was used.

\section{Morphological analyses of the male $A$. podana trapped by different attractant blends}

Correlation between the attractant component ratio and the percentage of $\mathrm{A}, \mathrm{L}$, $\mathrm{AL}$, and 0 phenotype males was tested by the $\chi^{2}$-test.

\section{RESULTS}

\section{Aedeagus variability}

On the basis of the number of spikes on aedeagus, four phenotypes of A. podana were identified in field trials in 2000. Our study of the main phenotypes within the species (Table 1) revealed that the northern Caucasian population consists mainly of L phenotype males (89\%), whereas A phenotype males dominate $(69-89 \%)$ in Baltic populations in Estonia and northwestern Russia.

The results of morphological analysis of A. podana males trapped by different attractants are summarized in Table 2 . There was no significant correlation between the attractant component ratio and the percentage of $\mathrm{A}, \mathrm{L}, \mathrm{AL}$, and 0 phenotypes in trap catch at $p<0.1$.

Table 1. Intraspecific variability of Archips podana in 2000 based on the position of spikes on the aedeagus. Males trapped by Z11-14:Ac and E11-14:Ac at a ratio $60: 40$

\begin{tabular}{|c|c|c|c|c|c|c|}
\hline \multirow[t]{2}{*}{ Collection locality } & \multirow[t]{2}{*}{ Country } & \multicolumn{4}{|c|}{ Phenotypes, no. (and \%) of males } & \multirow{2}{*}{$\begin{array}{c}\text { Total no. of males } \\
\text { A+AL+L+0 }\end{array}$} \\
\hline & & A & $\mathrm{AL}$ & $\mathrm{L}$ & 0 & \\
\hline Krasnodar & Russia & 0 & $1(0.2)$ & $423(89)$ & $52(11)$ & 476 \\
\hline Velikie Luki (orchard) & Russia & $565(69)$ & $87(11)$ & $89(11)$ & $72(9)$ & 813 \\
\hline Velikie Luki (forest) & Russia & $546(73)$ & $66(9)$ & $52(7)$ & $84(11)$ & 748 \\
\hline Pushkin & Russia & $8(89)$ & $1(11)$ & 0 & 0 & 9 \\
\hline Uhti (orchard) & Estonia & $282(84)$ & $16(5)$ & $16(5)$ & $20(6)$ & 334 \\
\hline Otepää (forest) & Estonia & $337(84)$ & $13(3)$ & $34(8)$ & $20(5)$ & 404 \\
\hline
\end{tabular}


Table 2. Phenotypes of Archips podana trapped by dispensers having variable ratio of 11-tetradecenyl acetate isomers in Russia at Velikie Luki in 1990

\begin{tabular}{l|c|ccc|c}
\hline \multirow{2}{*}{$\begin{array}{l}\text { Z11-14:Ac in } \\
\text { attractant, \% }\end{array}$} & Total trap catch, & \multicolumn{4}{|c}{ Morphological forms, \% } \\
\cline { 3 - 6 } & no. of males & A & AL & 0 & L \\
\hline 41 & 13 & 75 & 0 & 25 & 0 \\
51 & 17 & 45 & 18.2 & 27.3 & 9.1 \\
55 & 29 & 89 & 0 & 11 & 0 \\
59 & 97 & 45 & 10 & 32 & 12.5 \\
66 & 58 & 62.5 & 6.3 & 25 & 6.3
\end{tabular}

\section{Optimum ratio of isomers and width of the pheromone communication channel}

All the investigated A. podana populations had identical values of pheromone communication channel parameters. Optimal ratios of pheromone components and communication channel widths, calculated from the test results of 1990 and 1999 in different regions, are summarized in Table 3 and in Figs. 1-3.

Table 3. Optimum ratio of 11-tetradecenyl acetate isomers and the width of the pheromone communication channel of $A$. podana in different regions

\begin{tabular}{l|c|c|l|c|c}
\hline \multicolumn{1}{c|}{ Region } & Year & $\begin{array}{c}\text { Insect } \\
\text { generation }\end{array}$ & Biotope & $\begin{array}{c}\text { Optimum content of } \\
\text { Z isomer, \% }\end{array}$ & $\begin{array}{c}\text { Channel width, } \\
\%\end{array}$ \\
\hline Velikie Luki & 1990 & I & Orchard & $62.2 \pm 1.4$ & 9.3 \\
Krasnodar & 1990 & I & Orchard & $60.2 \pm 1.0$ & 11.2 \\
Krasnodar & 1990 & II & Orchard & $62.9 \pm 1.6$ & 14.1 \\
Uhti & 1999 & I & Orchard & $61.2 \pm 1.8$ & 14.3 \\
Otepää & 1999 & I & Forest & $60.0 \pm 0.9$ & 9.8 \\
\multicolumn{1}{c}{ Mean } & & & & $61.3 \pm 1.3$ & $11.7 \pm 2.3$
\end{tabular}

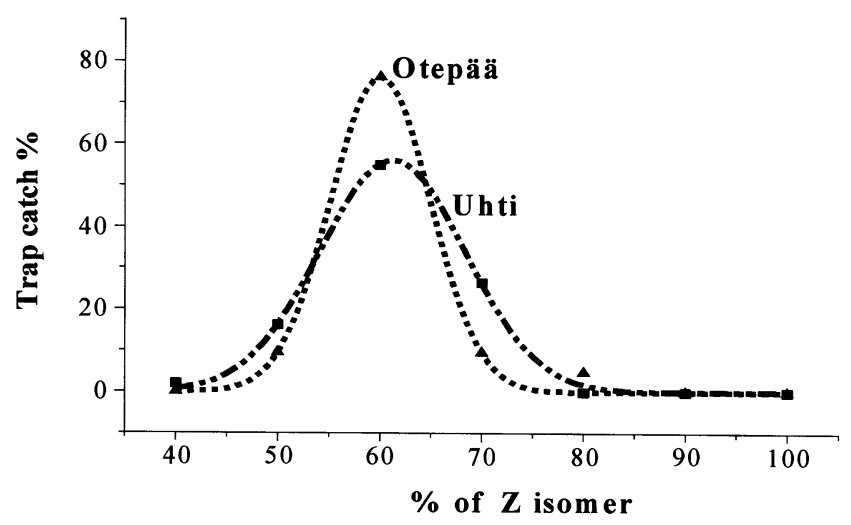

Fig. 1. Distribution of trap catches depending on the Z/E ratio in Estonia at Otepää (forest) and Uhti (orchard) in 1999. 


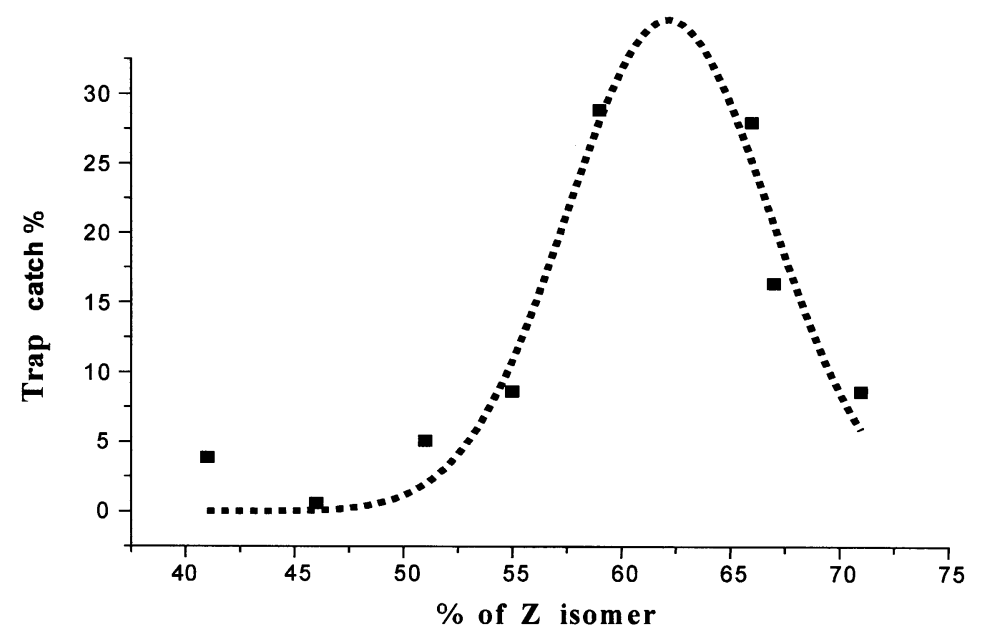

Fig. 2. Distribution of trap catches depending on the Z/E ratio in Russia at Velikie Luki (orchard) in 1990.

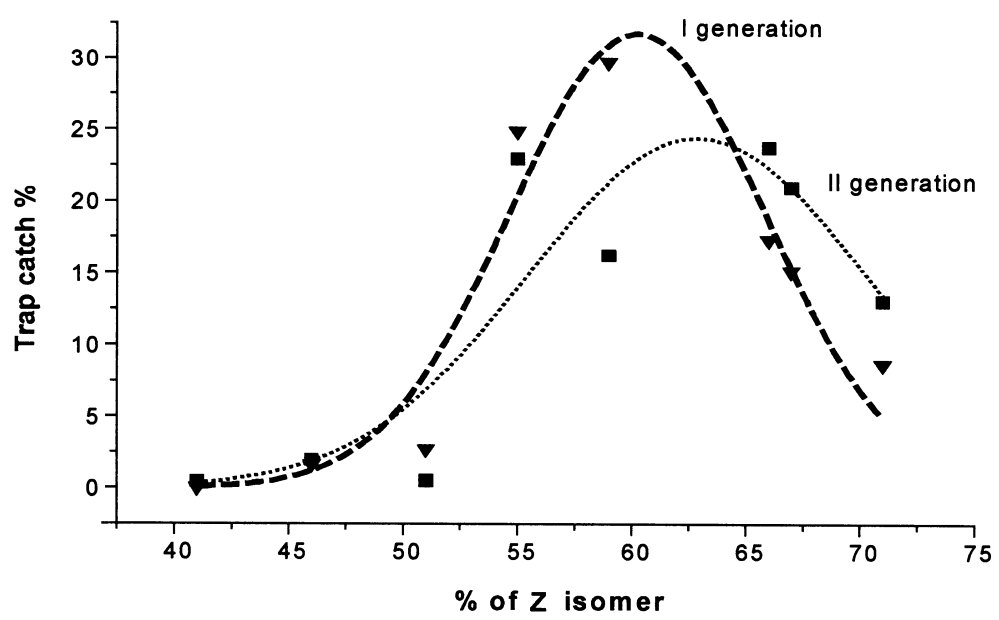

Fig. 3. Distribution of trap catches depending on the Z/E ratio in Russia at Krasnodar in 1990.

\section{DISCUSSION}

\section{Genital variability}

Insect genitalia are variable. In the monograph by Razowski (1981) on Tortricinae (including Archipini) we found at least 24 species for which he noted variability of male genitalia, especially the aedeagus. A great extent of variability (from 0 to 19 spikes on both sides of distal part) was also found on the aedeagus 
of Pandemis heparana Den. et Schiff. (Kozlov, 1991). Differences in genitalia of insects from different regions are the first step for speciation, and different forms are sometimes described as subspecies. Kozlov \& Esartia (1991) separated a Caucasian subspecies of A. podana (males phenotype L) as A. podana meridiana, while Brun et al. (1991) described it as the "Corsican variety" of A. podana.

In our experiments in Estonia, northwestern Russia (Velikie Luki and Pushkin), and northern Caucasus, the ratio of A. podana male phenotypes in trap catches entirely coincides with those mapped by Kozlov \& Motorkin (1990) (Table 1). The habitat (orchard or forest) had no influence in Estonia and northwestern Russia, and, as shown by Kozlov \& Motorkin (1988), in western Georgia. A large proportion of phenotype $\mathrm{L}(5-8 \%)$ in the northern populations and the variability in size of apical and lateral spikes testify that we are dealing with only one taxon of specific range. According to Safonkin (1987b, 1988, 1990), a possible explanation of the distribution pattern of phenotypes is climatic adaptation. However, the adaptation of $\mathrm{L}$ phenotype males to southern and A phenotype males to northern climate has not been proven experimentally. The fraction of LD decreased from 87 to $71 \%$ during 5 generations of laboratory population in Kozlov's (1989) experiments with the material collected from Georgia. As supposed by Kozlov, the decrease may be due to worse adaptability to some laboratory conditions or heredity.

In case the different phenotypes of A. podana have differences in pheromone communication channels the females should emit different pheromone blends. The variation of the pheromone structure in mono- and polymorphic populations of some groups of Lepidoptera are known (Löfstedt \& van der Pers, 1985; Löfstedt, 1990, 1991). The researches on the pheromone dialect of the noctuid Scotia (Agrotis) segetum (Den. et Schiff.), carried out in different countries of Europe, Asia, and Africa (Hansson et al., 1990; Tóth et al., 1992; Löfstedt, 1993; Wu et al., 1999) are of interest. In case of tortricids, Wen-jun et al. (1992) found sex pheromone polymorphism of Adoxophyes orana in China. Females taken from different cultures (apple and peach orchards, tea and cotton plantations) secrete sex pheromones with different blend component ratios.

\section{Identity of pheromone communication channels of phenotypes}

\section{Optimal component ratio}

Our experiments demonstrated the full identity of the pheromone communication channels of A. podana in the Krasnodar Territory, where the $\mathrm{L}$ phenotype dominates, and those in Velikie Luki and Estonia, where A phenotype males dominate. On average, the optimal ratio of 11-tetradecenyl acetate isomers was $61.3 \pm 1.3 \%$ of Z11-14:Ac (Table 3). Analysis of the results of experiments carried out in Velikie Luki in 1990 demonstrated that a deviation of the attractive blend from the optimal ratio causes a comparable decrease in trap catches for males of different aedeagus forms (Table 2). The calculated percentages in trap catches scatter irregularly, but the differences are not significant. 
In some papers, diverse values of the optimal isomer ratio have been published (Persoons et al. 1974; Frérot et al., 1979; Ivanova \& Mõttus, 1986a). It may be due to insufficient purity of isomers used. Different load doses of a blend do not cause differences in trap catches in case of an optimal ratio of blend components (Liblikas et al., in prep.).

\section{Communication channel width}

The mean value of pheromone communication channel width was $11.7 \pm 2.3 \%$ of Z11-14:Ac in all test locations (Table 3). This figure is typical of many Tortricidae moths (Ojarand et al., 2000; Mõttus et al., 2001). Shapes of activity curves for the A. podana populations were identical in orchards (Figs. 1-3) and in forest (Fig. 1).

The results described here demonstrate lack of variation in the optimal ratio of Z11-14:Ac and E11-14:Ac for different phenotypes of A. podana.

\section{Influence of impurities}

Commercial Z11-14:AC and E11-14:AC may contain some amount of the corresponding alcohol, Z11-14:OH and E11-14:OH. The synergistic activity of Z11-14:OH and E11-14:OH for A. podana was found in field tests in the Krasnodar and Pskov regions (Mõttus \& Ivanova, 1991), Lagodekhi (Kozlov et al., 1991), and near Moscow (Safonkin, 2000), whereas no positive influence was recorded at Lipetsk and in the Voronezh area (Ryabchinskaya et al., 1986) and in Belarus (Mõttus \& Ivanova, 1991). The effect of the corresponding alcohols depends probably on abiotic factors, dispenser design, etc., and it cannot be referred to differences among phenotypes. This aspect has been studied in our laboratories and results are in preparation (Liblikas et al., in prep.).

\section{Taxonomic note}

A new subspecies of A. podana (A.p. meridiana), inhabiting Caucasus, Krasnodar, and Stavropol areas as well as the Crimea, was defined by Kozlov \& Esartia (1991) on the basis of three groups of characteristics: (1) frequency of the apical spike; frequency of the lateral spike; fraction of males having only an apical spike on the aedeagus; (2) size of the apical spike; distance of the apical spike from the apex of the aedeagus; direction of the apical spike; and (3) attractiveness of synthetic sex attractant blend (ratio of components, $5: 5$ or $6: 4$ ) and influence of 1:1 mixture of (Z11-14:AC):(E11-14:AC) (inhibitory or synergistic action). According to the authors, the subspecies differs from the nominotypical subspecies in absence of the apical spike on the aedeagus.

At the same time, A. p. podana populations vary greatly in the frequency of the apical spike, from 10 to $72 \%$ of the males in various samples have no apical spike or have it associated with the lateral spike (Kozlov \& Esartia, 1991). The variation has been confirmed by our results. For example, the variation in different populations of Estonia and northwestern Russia is between 11 and 31\% (Table 2).

According to the "75\%-rule" (Mayr, 1971), at least $75 \%$ of the individuals in a population of one subspecies should differ from "all" (at least 97\%) individuals 
of another subspecies. In the case of A. p. meridiana, most specimens of A. p. meridiana population do not differ from at least $97 \%$ of $A$. p. podana males (89-100\% of males have no apical spike). Other morphological characteristics, used by Kozlov \& Esartia (1991), vary even to a greater extent than the frequency of the apical spike and have no taxonomic value. The identity of the optimal ratio of the pheromone components for Caucasian, northwestern Russian, and Estonian populations was demonstrated above. Therefore, a new subspecies of A. podana (A. p. meridiana Kozlov et Esartia), defined by Kozlov \& Esartia (1991), is identical to Archips podana (Scopoli).

\section{Normal distribution of attractivities}

Regression analysis of the distribution of attractivities of different attractant blends by means of Gaussian or normal distribution enables to calculate the width and optimal composition of binary pheromone blends (Ojarand et al., 2000; Mõttus et al., 2001). It is evidently more informative than comparison of attractivities of different blends and enables quantitative prediction of trap catch results.

For instance, a pheromone dispenser for A. podana has maximum attractivity if the content of Z11-14:Ac in effluvia makes up 60\%, in case the ratio of components differs by $\pm \sigma( \pm 6 \%)$, trap catch equals $61 \%$ of the maximum and in case of a difference of $\pm 0.4 \sigma$ ( $3 \%$ of Z11-14:Ac), the mean trap catch diminishes to $10 \%$.

\section{CONCLUSIONS}

Evaluation of the pheromone communication channel within different dominating A. podana phenotypes in northwestern Russia, Estonia, the Caucasus, and the adjacent steppe zone revealed an identical optimal pheromone in all the tested areas. No evidence of pheromone dialect was established.

Fitting the normal distribution to field experiment data is an effective method for estimating the role of different blend components in chemical communication, for optimizing the composition of the blend, and for detecting intraspecific variability of pheromone communication.

A subspecies of A. podana (A. p. meridiana Kozlov et Esartia), defined by Kozlov \& Esartia (1991), is identical to Archips podana (Scopoli).

\section{ACKNOWLEDGEMENTS}

The authors thank Matti Mõttus and Sirje Kuusik for useful consultations and analyses, AS Hevea (Tallinn, Estonia) for the substrate for Miniket dispensers, and AS Flora (Tartu, Estonia) for Feroflor type dispensers. The support by the Estonian Government Grant No. 0422104s02, VISBY program "Ecological chemistry and the control of insect pests", and ETF grant 5085 is acknowledged. 


\section{REFERENCES}

Brun, P., Chambon, J.-P. \& Frérot, B. 1991. Piègeage sexuel des mâles de Lepidopteres Tortricidae en Corse par les attractifs de synthèse. Nouv. Rev. Entomol. N.S., 8, 37-42.

Bykhovets, A. L., Akhrem, A. A., Lakhvitch, F. A., Petrusevitch, I. I., Zolotar, R. M., Zhukov, N. M., Beglyakova, T. M., Antonova, S. V., Kazytsits, A. V., Mõttus, E. R. \& Laanmaa, M. K. 1986. Field bioassay of moths sex attractants. In Pheromones of Tortricids - Agricultural Pests (Shumakov, Y. M. \& Mõttus, E. R., eds.), pp. 36-48. Tartu (in Russian).

Frérot, B., Descoins, S., Lalanne-Cassou, B., Sageio, P. \& Beauvais, F. 1979. Essais de piègeage sexuel des lepidoptera Tortricidae des vergers de pommiers par des attractifs de synthèse. Ann. Zool. Ecol. Anim., 11, 617-636.

Galetenko, S. M. 1964. Contribution to morphology of fruit-leaf-rollers in the Crimea. In 150 Years of State Nikitskij Botanical Garden. Collection of Research Papers, 37, 531-595 (in Russian).

Hannemann, H. J. 1963. Verzeichnis der deutschen Microlepidopteren I. Tortricidae s.str. Dtsch. Entomol. Z., 10, 323-330.

Hansson, B. S., Tóth, M., Löfstedt, C., Szöcs, G., Subchev, M. \& Löfqvist, J. 1990. Pheromone variation among eastern European and a western Asian population of the turnip moth Agrotis segetum. J. Chem. Ecol., 16, 1611-1622.

Howse, P. E., Jones, O. T. \& Stevens, I. D. R. 1998. Pheromones and Their Use in Pest Management, pp. 7-12. Chapman and Hall, London.

Ivanova, T. V. \& Mõttus, E. 1986a. Heterogenity of geographical population of Archips podana. In Chemical Communication of Animals. Theory and Practice (Sokolov, V. E., ed.), pp. 79-82. Moscow (in Russian).

Ivanova, T. V. \& Mõttus, E. 1986b. The interaction of synthetic sex pheromone components in some Tortricidae pests of orchards. Tr. Vses. Entomol. O-va, 68, 144-148 (in Russian).

Kozlov, M. V. 1989. Shift of phenetic population structure characteristics of Archips podana (Lepidoptera, Tortricidae) in case of pheromone trapping of males. Dokl. Akad. Nauk SSSR, 308, 1018-1020 (in Russian).

Kozlov, M. V. 1990. The use of leaf roller male genitalia variability (Papilionidae, Tortricidae) for study of population structure of a species. In Advances of Entomology in the USSR: Hymenoptera and Lepidoptera (Medvedev, G. S., ed.), pp. 173-176. Zoologicheskii institut AN SSSR, Leningrad (in Russian).

Kozlov, M. V. 1991. The male genitalia variability of leaf roller Pandemis heparana Den. et Schiff. (Lepidoptera, Tortricidae) and methods of its analysis. Biol. Nauki, 3, $48-59$ (in Russian).

Kozlov, M. V. \& Esartia, G. K. 1991. The new subspecies of Archips podana Scop. (Lepidoptera, Tortricidae) from Caucasus. Vestn. Zool., 1, 33-36 (in Russian).

Kozlov, M. V. \& Kravchuk, A. N. 1991. Peculiarites of perception of a synthetic sex attractant in different forms of male leafroller Archips podana. Zh. Evol. Biokhim. Fiziol., 27, 182-189 (in Russian).

Kozlov, M. V. \& Motorkin, M. E. 1987. Individual variability in genitals of leaf roller Archips podana Scop. (Lepidoptera, Tortricidae) males. Byull. Vses. Nauchno-Issled. Inst. Zaschch. Rast., 68, 53-55 (in Russian).

Kozlov, M. V. \& Motorkin, M. E. 1988. Application of synthetic sex attractants for investigation of phenetic structure of Archips podana in the Eastern Georgia. In Insect Pheromones and Their Practical Application, pp. 23-30. VIZR, Leningrad (in Russian).

Kozlov, M. V. \& Motorkin, M. E. 1990. The geographical variability of leaf roller Archips podana (Lepidoptera, Tortricidae). Zool. Zh., 69, 55-62 (in Russian).

Kozlov, M. V., Vrkoc, J. \& Zvereva, E. L. 1991. Investigation of geographical variability of responses to sex attractants in leafrollers. In Insect Chemical Ecology. Proceedings of Conference held in Tabor, Czechoslovakia (Hrdy, I., ed.), pp. 97-100. The Hague. 
Kuznetsov, V. I. 1978. Tortricidae. Keys to the European Part of the USSR. Vol. 4, Part 1. Lepidoptera, pp. 193-680. Nauka, Leningrad (in Russian).

Kuznetsov, V. I. 1994. Tortricidae. Insects and Mites, Pests of Agricultural Plants. Vol. 3, Part 1. Lepidoptera, pp. 51-234. Nauka, Sankt-Peterburg (in Russian).

Litvinova, A. N. 1974. On the food specificy of Archips podana Scop. and some other leafrollers. Vopr. Entomol., 97-112 (in Russian).

Löfstedt, C. 1990. Population variation and genetic control of pheromone communication systems in moths. Entomol. Exp. Appl., 54, 199-218.

Löfstedt, C. 1991. Evolution of moth pheromones. In Insect Chemical Ecology. Proceedings of Conference held in Tabor, Czechoslovakia (Hrdy, I., ed.), pp. 57-73. The Hague.

Löfstedt, C. 1993. Moth pheromone genetics and evolution. Philos. Trans. R. Soc. Lond. B, 340, 167-177.

Löfstedt, C. \& van der Pers, J. N. C. 1985. Sex pheromones and reproductive isolation in four European small ermine moths. J. Chem. Ecol., 11, 649-666.

Mayr, E. 1971. Principles of Systematic Zoology. Mir, Moscow (in Russian) [1969, McGraw Hill, New York].

Mõttus, E. \& Ivanova, T. 1991. Attractant specificity and interactions among pheromone components of orchard moth pests. In Insect Chemical Ecology. Proceedings of Conference held in Tabor, Czechoslovakia (Hrdy, I., ed.), pp. 81-96. The Hague.

Mõttus, E., Liblikas, I., Ojarand, A., Martin, M. \& Borg-Karlson, A.-K. 2001. Attractivity of 11-tetradecenyl acetate isomers for Archips podana Scopoli and Aphelia paleana (Hübner). Norw. J. Entomol., 48, 77-86.

Ojarand, A., Mõttus, E. \& Liblikas, I. 2000. Calculation of the width of Archips podana pheromone communication channel. In Development of Environmentally Friendly Plant Protection in the Baltic Region (Metspalu, L. \& Mitt, S., eds.), pp. 146-149. Tartu.

Persoons, C. J., Minks, A. K., Voerman, S., Roelofs, W. L. \& Ritter, F. J. 1974. Sex pheromones of the moth, Archips podana: isolation, identification and field evaluation of two synergistic geometrical isomers. J. Insect Physiol., 20, 1181-1188.

Razowski, J. 1977. Monograph of the genus Archips Hubner (Lepidoptera, Tortricidae). Acta Zool. Krakov, 22, 55-205.

Razowski, J. 1981. Motyle (Lepidoptera) Polski. V. Cossoidea i Tortricinae. Monogr. Fauny Pol., 1981, 10, 345 (in Polish).

Ryabchinskaya, T. A., Mõttus, E. R. \& Kolesova, D. A. 1986. Pheromone dispensers for Archips podana Sc. (Lepidoptera: Tortricidae). In Protection of Agricultural Plants Against Harmful Organisms, pp. 73-79. Voronezh (in Russian).

Safonkin, A. F. 1987a. Reaction of males Archips podana (Lepidoptera, Tortricidae) to synthetic attractants in relation to polymorphism of the genitalia. Zool. Zh., 66, 1423-1426 (in Russian).

Safonkin, A. F. 1987b. Population infrastructure of leafroller Archips podana (Lepidoptera, Tortricidae) in relation to inhabitancy on different host plants. Dokl. Akad. Nauk SSSR, 296, 510-512 (in Russian).

Safonkin, A. F. 1988. Male reactions of Archips podana Scop. and Laspeyresia pomonella (Lepidoptera, Tortricidae) by the interaction of sex attractants of these species. Zool. Zh., 67, 1423-1426 (in Russian).

Safonkin, A. F. 1989. Complex composition of pheromone signal and reproductive strategy of leaf rollers (Lepidoptera: Tortricidae). Dokl. Akad. Nauk SSSR, 309, 1502-1505 (in Russian).

Safonkin, A. F. 1990. Polymorphism and ecological plasticity of leaf roller Archips podana Sc. (Lepidoptera, Tortricidae). Zh. Obshch. Biol., 51, 393-400 (in Russian).

Safonkin, A. F. 2000. Polymorphism and chemocommunication of Archips podana (Lepidoptera: Tortricidae). Byull. Mosk. O. Ispyt. Prir. Otd., Biol., 105, 21-25 (in Russian).

Safonkin, A. F. \& Buleza, A. F. 1988. Role of sex pheromones in intraspecific isolation of leaf rollers (Lepidoptera: Tortricidae). Zh. Obshch. Biol., 49, 396-400 (in Russian). 
Sokal, R. R. \& Rohlf, F. J. 1986. Biometry: The Principles and Practice of Statistics in Biological Research. W. H. Freeman and Company, New York.

Tóth, M., Löfstedt, C., Blair, B., Cabello, T., Farag, A. I., Hansson, B. S., Kovalev, B. G., Maini, S., Nesterov, E. A., Pajor, I., Sazonov, P., Shamshev, I. V., Subchev, M. \& Szöcs, G. 1992. Attraction of male turnip moths Agrotis segetum (Lepidoptera: Noctuidae) to sex pheromone components and their mixtures at 11 sites in Europe, Asia and Africa. J. Chem. Ecol., 18, 1337-1347.

Wen-jun, Fu, Chang-ben, Huang, Guo-ming, Chen, Song-yun, Vu. 1992. Sex pheromone polymorphism of summer fruit-tree tortrix moth Adoxophyes orana (Lep.: Tortricidae) in China. In Proc. 19th Intern. Entomol. Congr. Beijing, China, p. 220.

Wu, W., Cottrell, C. B., Hansson, B. S. \& Löfstedt, C. 1999. Comparative study of pheromone production and response in Swedish and Zimbabwean populations of turnip moth, Agrotis segetum. J. Chem. Ecol., 25, 177-196.

\title{
Archips podana (Scopoli) genitaalpreparaatide ja feromoonkommunikatsioonikanali varieeruvus
}

\author{
Ilme Liblikas, Enno Mõttus, Zoja V. Nikolajeva, Ann Ojarand, \\ Anna-Karin Borg-Karlson, Jelena I. Ovsjannikova, Igor J. Gritšanov, \\ Tamara V. Ivanova ja Viktor A. Jemeljanov
}

Suur taramähkur Archips podana (Scopoli) on levinud kõikjal Euroopas. Selle liigi isaste genitaalpreparaadid varieeruvad aedeaguse kidade asendi ja arvu poolest. Kidad võivad asuda apikaalselt (vorm A) või lateraalselt (L), samuti võivad need puududa (0). On leitud ka mitme kidaga vorme $2 \mathrm{~L}, \mathrm{AL}$ ja A2L. Varasemates artiklites on viidatud võimalusele, et erinevate genitaalpreparaatidega taramähkurid võivad erineda ka feromoonkommunikatsiooni osas. Käesolevas töös on esitatud uurimistulemused A. podana isasloomade genitaalpreparaatide erinevusest Eestis (Uhti õunaaed ja segamets Otepää lähistel), ounaaedades LoodeVenemaal Leningradi oblastis ja Velikije Lukis (Pihkva oblast), samuti LõunaVenemaal Krasnodari krais Slavinski linna lähistel.

Feromoonainete segu aktiivsuste hindamisel Gaussi normaaljaotuse alusel selgus, et suure taramähkuri isasloomadele osutus kõikjal aktiivseimaks Z-11-tetradetsenüülatsetaadi (Z11-14:Ac) ja selle trans-isomeeri E11-14:Ac segu, mis sisaldas $61,3 \pm 1,3 \%$ Z-isomeeri. See on Persoonsi jt poolt 1994. a identifitseeritud feromooni koostisega praktiliselt kokkulangev. Kuna Krasnodari krais domineerib L-tüüpi A. podana, Põhja-Euroopas aga A-tüüp, siis selle liigi isaste genitaalpreparaatide varieeruvus ei seondu muutustega reaktsioonis feromoonile. Tuginedes genitaalpreparaatide erinevusele ja oletatavale varieeruvusele feromooni retseptsioonis, kirjeldasid Kozlov ja Esartia (1991) isaste fenotüüpi L kui A. podana alamliiki A. podana meridiana Kozl. et Esart. Käesolevas artiklis toodud materjalide alusel puuduvad sellise alamliigi eraldamiseks alused. Üheks oluliseks järelduseks uurimusest loeme asjaolu, et feromoonkommunikatsiooni parameetrite, aktiivsuste maksimumi ja aktiivsuste jaotust saab kasutada nii putukate kui ka feromoondispenserite omaduste hindamiseks. 